\title{
Approach to evaluation of car seats fabrics performance
}

\section{REZUMAT - ABSTRACT}

\section{Evaluarea performanței țesăturilor pentru scaunele auto}

Acest studiu investigează performanța țesăturilor pentru scaunele auto privind compresia, proprietățile de recuperare şi confortul fiziologic al statului pe scaun. Spuma poliuretanică, nețesutele şi țesăturile tricotate 3D Spacer sunt utilizate în mod obişnuit pentru căptuşeala (în stratul intermediar) huselor pentru scaunele auto. Studiul prezintă o abordare alternativă pentru evaluarea eficienței țesăturilor pentru scaunele auto, şi anume comportamentul lor de compresie, variația în grosime la încărcarea dinamică, proprietățile termice, rezistența la vapori de apă şi permeabilitatea la aer. Proprietățile menționate aparțin cerințelor de bază în fabricarea scaunelor auto. Sistemul de micro-tomografie a fost utilizat pentru a obține informații detaliate despre schimbarea structurii interne a probelor de țesătură, înainte şi după testul de compresie.

Cuvinte-cheie: scaune auto, compresie, recuperare, rezistență termică, micro-tomografie

\section{Approach to evaluation of car seats fabrics performance}

This paper deals with investigating performance of car seat fabrics in terms of their compression and recovery properties and physiological comfort of sitting. Polyurethane foam, nonwoven and 3D knitted spacer fabrics are commonly used as padding (in middle layer) in car seats cover. The current work presents an alternative approach to evaluate effectivity of car seat fabrics, namely their compression behaviour, variation in thickness under dynamic loading, thermal properties, water vapour resistance and air permeability. The above mentioned properties belong to basic requirements in car seat manufacturing. Micro tomography system was used to obtain detailed information about change in internal structure of fabric samples, before and after compression test.

Keywords: car seats, compression, recovery, thermal resistance, micro tomography

\section{INTRODUCTION}

Till date, a lot of research work has been devoted to comfort in automotive seating [1-2]. A seat is built in three parts: a metal armature, foam injected in a matrix (cushion), and textile structures (fabric) which cover the foam and armature. There are approximately 3-5 kg car seat cover fabrics used in each car [3]. Car seat covers are often composed of several layers of different materials, usually polyester fabric (or leather or synthetic leather) laminated to polyurethane foam (or 3D knitted spacer or nonwoven) backing by an adhesive. Each part of car seat cover brings different properties which affect both their durability and comfort in automotive seating. More recently, car producers increasingly put emphasis on transport properties (heat, moisture, air) of car seat covers to ensure good physiological comfort of drivers. Therefore, the effect of heated seat on thermal comfort during the initial warm-up period, an ergonomic evaluation of thermal comfort inside a car, measurement of sweating bottom and others were investigated [2, 4-5]. Moisture management behaviour, thermal properties and air transport of 3D warp knitted spacer fabric (3D spacer) and polyurethane foam (PU foam), which are commonly used as padding in car seat cover, have been examined [6-9]. Thermal property of porous nonwoven materials was analysed too [10]. Further, the effect of filament cross section on the performance of automotive upholstery fabrics was evaluated from air permeability point of view [11]. Majority of researchers have reached the conclusion that appropriate choice of middle layer of car seat cover can improve physiological comfort even in complex car seats including PU cushion. But they cannot agree on whether PU foam or 3D spacer is better to be used as middle parts of car seat cover. One group of researchers prefer polyethylene terephthalate (PET) fibres for automotive application (both for top and middle layers) due to their superior properties, like a high tenacity, abrasion, light, heat and chemical aging, UV resistance, dimensional stability, recyclability etc. [8, 11-12]. The others are in favour of modified PU foam (in middle layer) because of their excellent elasticity and very good recovery to compression [12]. Study on comparison of quality for different types of seat cover padding was carried out from aspects of physiological properties and relaxation behaviour after static and dynamic loading [13]. The result of this study showed that warp knitted spacer fabrics demonstrate better recovery to compression, better thermal properties and better breathability as compared to PU foam. The other research found out that fabrics using monofilament as spacer yarn generally have higher compression 
resistance than multifilament yarns $[8,14]$. It is important to follow changing of inner structure of cover fabric under compression (caused by driver) to understand effect on transport properties. Nowadays micro tomography analysis is an appropriate tool for it [15, 16]. To evaluate the comprehensive effectivity of car seat cover, a combination of comfort and durability behaviour must be investigated not only by tenacity and abrasion but also by studying mechanical stresses which the seats are subjected to, during the lifetime of the car. Major car manufacturers evaluate degree of car seat durability, including relaxation behaviour after cyclic loading by special equipment, which uses the robot - Occubot VI. Robot allows realistic simulation, of someone getting into and out of the seat (ingress/egress test), or of strong pulsation or vibration during driving [17]. Occubot is not often used for research in general because of high price and narrow specialization of mentioned equipment.

The current study is focused on complex evaluation of car seat fabrics in terms of their compression behaviour, thickness variation under dynamic loading, thermal properties, water vapour resistance, moisture management and air permeability. Further, the micro tomography system was used in order to obtain detailed information about change in inner structure of seat fabrics before and after compression test.

\section{EXPERIMENTAL DETAILS}

\section{Materials}

The experiment was divided into three steps. In the first step, six fabrics for car seats (group of the three different types of functional PES fibres in top layer of tested car seats in combination with different middle layers - polyurethane foam, nonwoven and 3D spacer), were analysed and compared in terms of their physiological behaviour. Second part was focused to investigation of thickness variation of tested fabrics under dynamic loading and their ability to recover compression. The third part of study was about change in internal structure of fabrics before and after dynamic compressive test by micro tomography system. The last two tests mentioned, were done with middle layer of car seat cover only. Tested materials were designed in order to understand the role of middle layer of textile sandwich car seats in their durability and physiological behaviour. Basic characteristics of all tested car seat fabrics are shown in table 1. SEM images of fibres used in weft and warp yarns from top layer of tested car seats (PES woven fabric) are shown in figure 1 and $3 D$ images of tested materials by micro tomography system SKY SCAN 1272, are shown in figure 2. Before being tested, the samples had been washed and conditioned for 24 hours. The measurement was carried out in an air-conditioned room under constant relative humidity of $65 \%$ and the temperature of $21^{\circ} \mathrm{C}$.

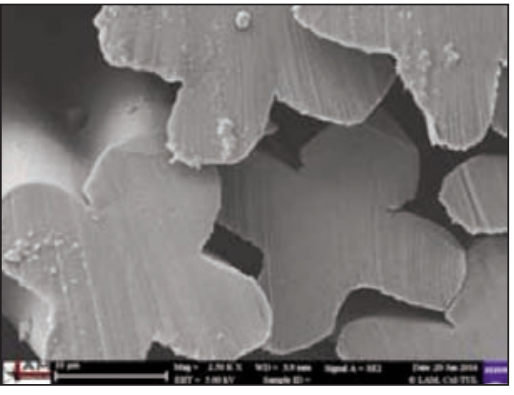

a

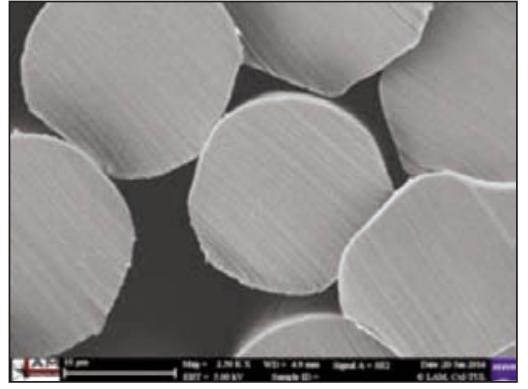

b

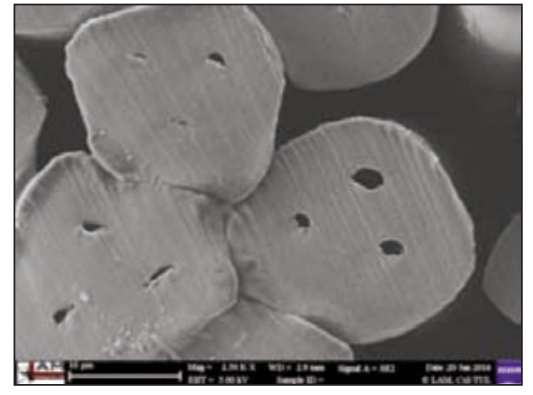

C

Fig. 1. SEM images of the single filaments: $a-\mathrm{A} 1 \mathrm{TOP}-$ tertalobal, $b-\mathrm{A} 2 \mathrm{TOP}-$ round, $c-\mathrm{A} 3 \mathrm{TOP}-\mathrm{hollow}$

Table 1

\begin{tabular}{|c|c|c|c|c|c|c|c|}
\hline \multicolumn{8}{|c|}{ BASIC CHARACTERISTICS OF TESTED MATERIALS } \\
\hline & Code & $\begin{array}{l}\text { Fiber } \\
\text { content }\end{array}$ & $\begin{array}{l}\text { Type } \\
\text { of fiber }\end{array}$ & Pattern & $\begin{array}{c}\text { Density } \\
\text { warp/weft } \\
\text { [thread/cm] }\end{array}$ & $\begin{array}{c}\text { Thickness } \\
\text { [mm] }\end{array}$ & $\begin{array}{l}\text { Mass } \\
{\left[\mathrm{g} / \mathrm{m}^{2}\right]}\end{array}$ \\
\hline \multirow{3}{*}{$\frac{\overbrace{0}^{\frac{1}{\sigma}}}{\frac{0}{0}}$} & A1 TOP - woven fabric & $100 \%$ PES & tetralobal & twill & $32 / 18.5$ & 0.81 & 233 \\
\hline & A2 TOP - woven fabric & $100 \%$ PES & round & twill & $32 / 18.5$ & 0.79 & 235 \\
\hline & A3 TOP - woven fabric & $100 \%$ PES & hollow & twill & $32 / 18.5$ & 0.69 & 203 \\
\hline \multirow{5}{*}{ 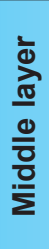 } & B1 - weft knitted spacer & $100 \%$ PES & - & - & - & 4.7 & 331 \\
\hline & B2 - warp knitted spacer & $100 \%$ PES & - & - & - & 6.73 & 508 \\
\hline & C1 - foam & $100 \%$ PUR & - & - & - & 7.03 & 247 \\
\hline & C2-foam & $100 \%$ PUR & - & - & - & 6.42 & 226 \\
\hline & D - nonwoven padding & $75 \%$ PES/30\%WO & - & - & - & 4.74 & 230 \\
\hline
\end{tabular}

Note: Measurement of thickness were performed under 1000 Pa pressure for top layers, 100 Pa for middle layers. 


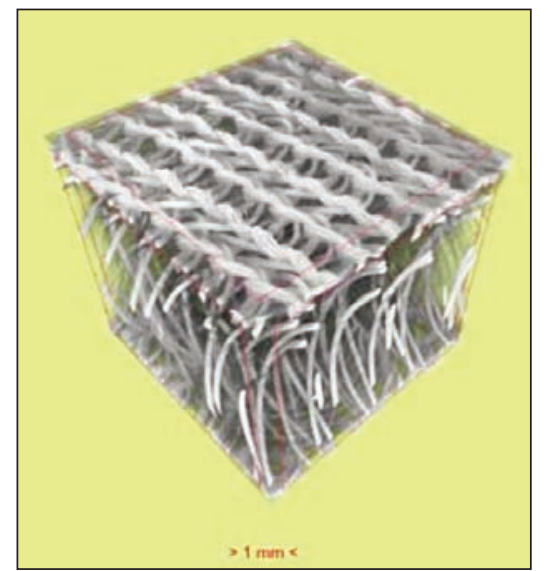

a

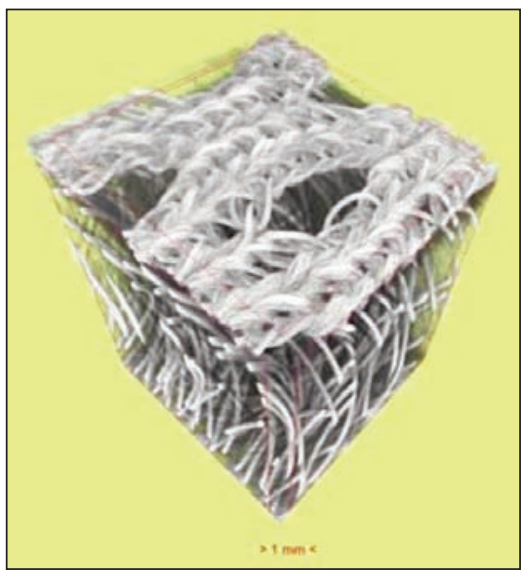

$\boldsymbol{b}$

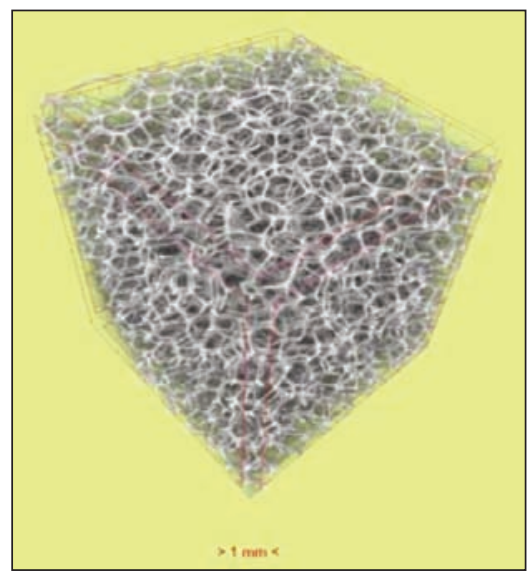

$\boldsymbol{C}$
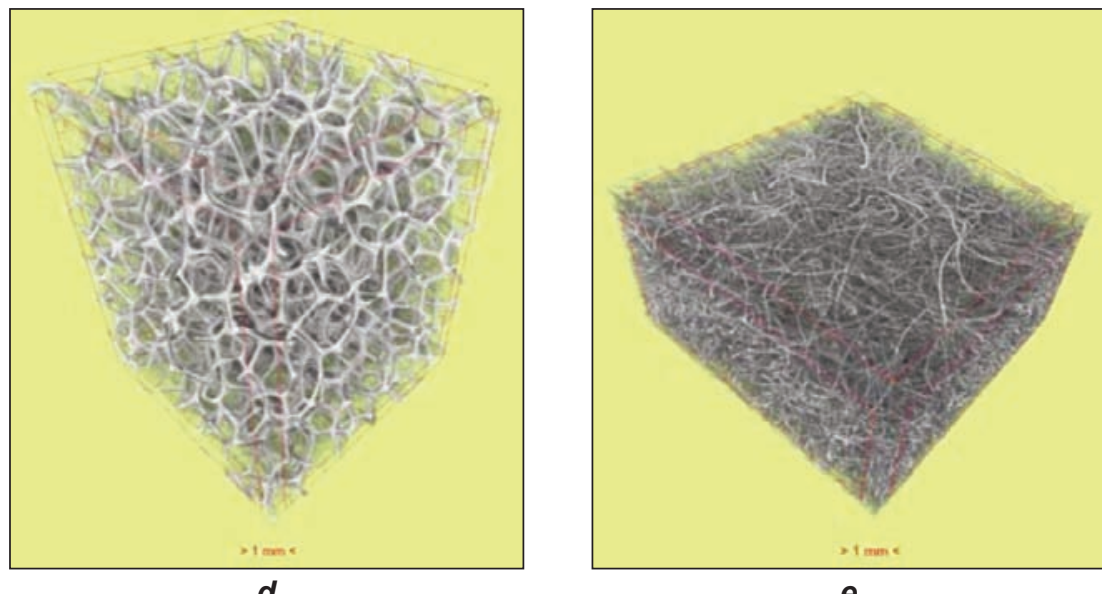

Fig. 2. 3D images of tested materials by micro tomography system SKY SCAN 1272: a - B1 - weft knitted spacer, $b-\mathrm{B} 2$ - warp knitted spacer, $c-C 1-P U$ foam, $d-C 2-P U$ foam, $e-D-$ nonwoven padding

\section{Methods}

The performance of car seat fabrics were investigated by three ways

- the measurement of physiological properties such as thermal and water vapour resistance, air permeability and dynamic liquid transport properties of samples,

- the measurement of compressive characteristics, namely thickness variation under dynamic loading and relaxation behaviour of tested samples,

- the analysis of 3D images of car seat inner structure by micro tomography system.

The results from the above mentioned methods were compared and discussed in order to understand the real performance of tested materials. Final values (means) of all tested parameters correspond to five measurements on average. The coefficients of variation for all tests do not exceed $10 \%$ and are therefore not statistically significant.

\section{Measurement of physiological properties}

Thermal resistance and water vapour resistance Thermal resistance Rct $\left[\mathrm{m}^{2} \mathrm{~K} / \mathrm{W}\right]$ and water vapour resistance Ret [ $\left.\mathrm{m}^{2} \mathrm{~Pa} / \mathrm{W}\right]$ of samples were investigated in accordance with standard EN 31092:1993 (ISO 11092) by Sweating Guarded Hotplate System 8.2 (SGHP).
The SGHP device is often referred to as 'skin model". The test simulates the transfer processes of heat and moisture through material next to skin and measures the rate of transfer of heat or moisture in such processes. The standard defines the setting up of the following conditions: an air temperature of $35^{\circ} \mathrm{C}$ and a relative humidity of $40 \%$ for measurement of water vapour resistance, and an air temperature of $20^{\circ} \mathrm{C}$ and a relative humidity of $65 \%$ for measurement of thermal resistance. Both types of measurements were carried out under the air velocity of $1 \mathrm{~m} / \mathrm{s}$.

\section{Air permeability}

Air permeability of tested samples were carried out in accordance with standard EN ISO 9237:1995 using device TEXTEST FX 3300.

\section{Dynamic liquid transport properties by MMT}

The moisture management tester (MMT) was developed to quantify dynamic liquid transport properties of knitted and woven fabrics through three dimensions:

- absorption rate - time for absorption of moisture on fabric's face and back surfaces;

- one-way transportation capability - one-way transfer from the fabric's back surface to its face surface;

- spreading/drying rate - the speed at which liquid moisture spreads across the fabric's back and face surfaces. 
MMT works in according to AATCC Test Method 195 - 2011 and consists of upper and lower concentric moisture sensors. The specimen is held flat under a fixed pressure between the sensors while standard test solution is introduced to the back surface of the fabric. Electrical resistance changes between the upper and lower sensors which are then recorded dynamically. Based on the changes of electrical resistance, several parameters are determined. These parameters are described in detail in Hu's work and other research [18]. Two parameters were analysed in this study: OMMC [-] - overall moisture management capacity and OWTC [-] - cumulative one-way transport capacity.

OMMC is an index which indicates the overall ability of the fabric to manage the transport of liquid moisture, which includes three aspects of performance: the moisture absorption rate of the face side, oneway liquid transport ability, and moisture drying speed of the face side, which is represented by the maximum spreading speed [18].

OWTC is defined as the difference in the cumulative moisture content between the two surfaces of the fabric in the unit testing time period [18]. Negative values mean that the cumulative moisture content on the top surface of the fabric is higher than on the bottom.

\section{Compression characteristics}

\section{Thickness variation under dynamic loading, relaxation behaviour}

To study the thickness variation of middle layer of car seat fabrics under dynamic loading, the measurement device shown in figure 3 was used. This instrument was developed at Technical University in Liberec [19]. A pressure plate with contact area of $28 \mathrm{~cm}^{2}$ (diameter is $6 \mathrm{~cm}$ ) moved up and down with frequency of 500 cycles per min, applying a dynamic load of $20 \mathrm{kPa}$ on the samples. One million of cycles were applied to each tested sample to simulate real condition of driver's sitting.

The thickness of tested samples was measured by compression tester SDL M 034A according to EN ISO 5084 both before and after dynamic loading.

Further, relaxation behaviour given by the thickness recovery of samples was investigated after above mentioned compression test, when load was removed. Specifically, the measurement was carried out immediately, 2 hours (h), $4 \mathrm{~h}$ and $24 \mathrm{~h}$ after test.

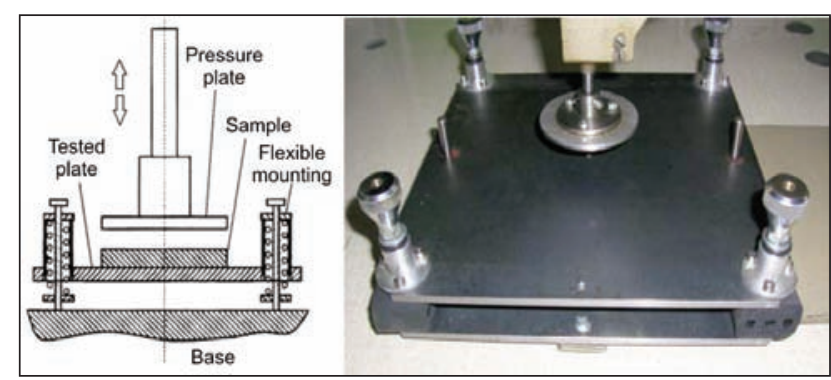

Fig. 3. Instrument for compression test [19]
All measurements of thickness were performed under $100 \mathrm{~Pa}$ pressure.

There are two types of spacer fabrics: warp and weft, two types of PU foam and one nonwoven's padding which were measured.

\section{Micro tomography analysis}

The computed micro tomography system SKYSCAN 1272 was used to investigate the change of inner structure of tested fabrics before and after compressive dynamic loading test. The micro CT system obtains multiple $x$-ray "shadow" transmission images of the object from multiple angular views as the object rotates on a high-precision stage. From these shadow images, cross-section images of the object are reconstructed using a special algorithm, creating a complete 3D representation of internal microstructure and density over an investigator-selected horizontal region in the transmission images. Measurements were taken under the following settings: image pixel size $-4,67 \mu \mathrm{m}$, rotation step $0.2^{\circ}$, rotation degrees $180^{\circ}$, frame averaging 3 , exposure $320 \mathrm{~ms}$, voltage source $40 \mathrm{kV}$. These conditions appeared as the best from both improved scanning speed and the quality of the scanned image. The above mentioned conditions are common for all tested materials. The parameters porosity [\%], distribution of porosity determined by percent volume in range of pores [\%] and connectivity $\left[1 / \mathrm{mm}^{3}\right]$ were established from 3D images of tested materials. Connectivity is defined as the maximal number of branches that may be cut without separating the structure [20].

\section{RESULTS AND DISCUSSION}

\section{Physiological properties}

To study the physiological properties of sandwich structures of car seat fabrics (different top layer connected with different middle layer by lamination), samples $A 1, A 2, A 3$ in combination $B 1, C 1, D$ were chosen. Totally, group of 9 car seat structures were tested by means of SGHP 8.2, MMT and TEXTEST FX 3300 to investigate transport of heat, water vapour, liquid water and air. Further, we work on an assumption, that different fibre cross section affects transport properties of samples as was presented in study of Koc [11]. Therefore top layers A1, A2, A3 are different in terms of functional PES fibres with follow cross section: round, tetralobal and hollow profile. There are 3D spacer, foam and nonwoven (B1, C1, D) used in middle layer of car seats fabric.

\section{Thermal resistance and water vapour resistance}

The results of water vapour resistance Ret $\left[\mathrm{m}^{2} \mathrm{~Pa} / \mathrm{W}\right]$ and thermal resistance Rct $\left[\mathrm{m}^{2} \mathrm{~K} / \mathrm{W}\right]$ are shown in figure 4 .

There is significant difference among values of Ret and Rct of tested samples in the figure 4. Foam C1 shows two times bigger value of Ret than nonwoven $\mathrm{D}$ and $3 \mathrm{D}$ spacer $\mathrm{C} 1$. It means that foam, which is the most frequently used material in car seat fabrics, 

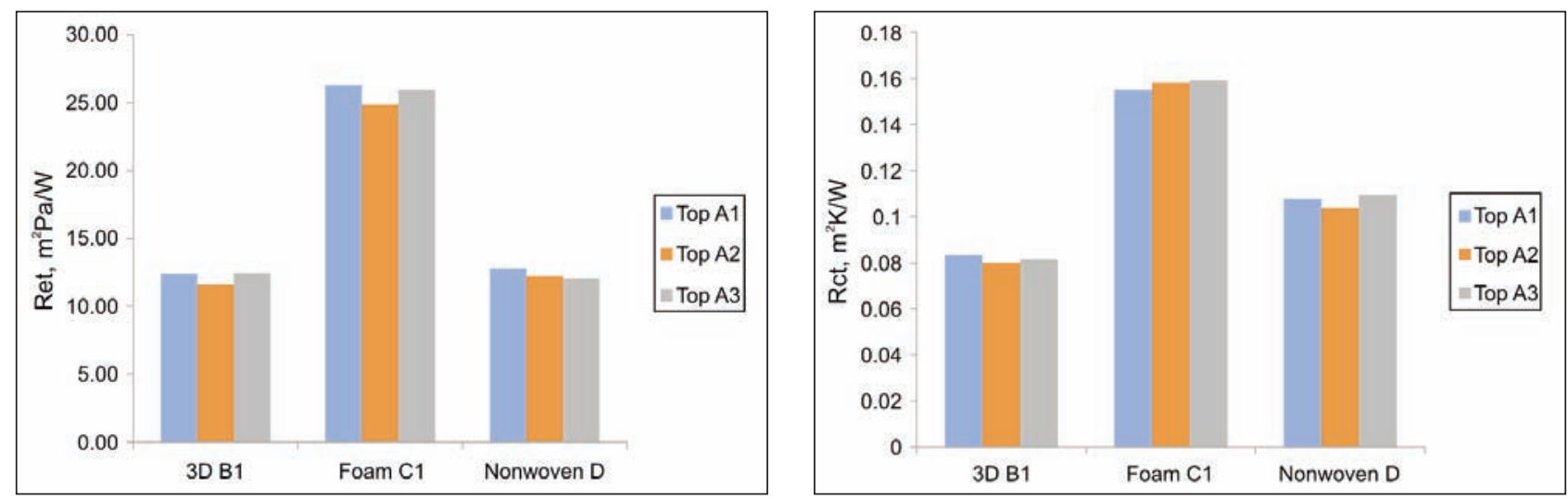

Fig. 4. Water vapor permeability (Ret) and thermal resistance (Rct) of samples

provides the least physiological comfort. The similar idea is valid for interpretation of thermal resistance results. In the case of ambient temperature inside the car, driver's body temperature is higher than temperature of car seat fabrics which results in good comfort feeling of drivers. On the other hand combination of heating of seat and low thermal insulation of car seat structures provide the faster transport of heat to skin of driver in winter. Among all the samples tested, 3D spacer fabric meets most of the aforementioned requirements. The assumption that the fibre cross section of top layer affects the transport properties of complex car seat structures has not been clearly proven. The difference of Ret and Rct values on the basis of fibre cross-section in top layers A1, A2, A3 is not significant as shown figure 4 .

\section{Dynamic liquid transport properties by MMT}

Further moisture transport of top layers (A1 TOP, A2 TOP and A3 TOP) was investigated by MMT. The results of dynamic liquid transport properties are very similar for all three layers and are shown in figure 5. In summary, these results indicate that all three samples of top layer can be characterized as water proof fabrics. It means that the fabric is not wetted, the solution is absorbed very slowly or not at all, the liquid is spreading through the fabric very slowly or not at all and neither one-way transport between surfaces of fabric nor any penetration occurs (cumula-

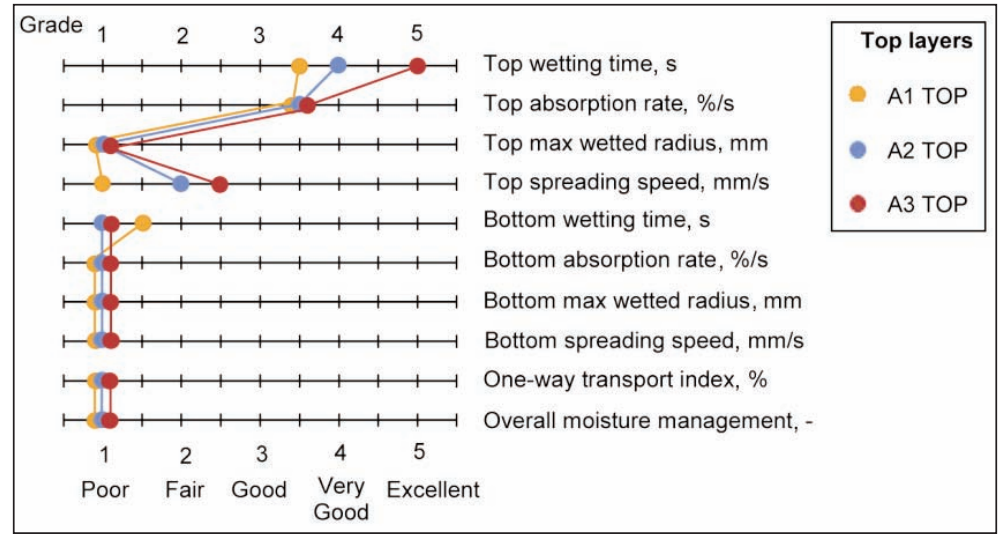

Fig. 5. Finger print of Moisture Management Properties tive moisture content stays on the top surface where it was applied).

\section{Air permeability}

The results of air permeability of tested car seat covers are shown in figure 6. The foam has the lowest level of air permeability. Air permeability of the 3D spacer B1 is even twice as PU foam. Generally, an assumption that $3 \mathrm{D}$ spacers provide better comfort properties than PU foam was validated [13]. Furthermore, influence of fibres cross section (of TOP layer of car seat cover) on degree of air permeability was confirmed too [11]. TOP A3 - top layers made from hollow fibres - show higher air permeability than TOP A1 - tetralobal or TOP A3 - round cross section. Increase of air permeability value of fibres with hollow cross section against tetralobal is about 44 to 70 per cent (according to used middle layer - foam, nonwoven, 3D spacer).

\section{- Compression characteristics}

\section{Thickness variation under dynamic loading, relaxation behaviour}

The results of compressibility performance, particularly relaxation behaviour of car seat fabrics are shown in figure 7 . The thickness variation of samples was measured both before and after dynamic compressive loading. Subsequently, relaxation behaviour of samples was determined by thickness recovery after compression test as follow: immediately after test, 0 hours (h), $2 \mathrm{~h}, 4 \mathrm{~h}$ and $24 \mathrm{~h}$ after test.

The curves showing the behaviour of materials B1, B2, C1 and C2 follow similar pattern, i.e. the thickness after dynamic loading (after 2 million cycles, at time 0 h) decreases in range between 1,6\% and $5,5 \%$ from initial value of thickness before test. After 2 million cycles, the 3D spacer B1 and B2 present the least change of thickness. On the contrary, there is significant reduction of thickness of nonwoven D (blue line) in figure 7 , about $22 \%$ of initial value of thickness.

With regard to thickness recovery, the results of all tested samples (including 


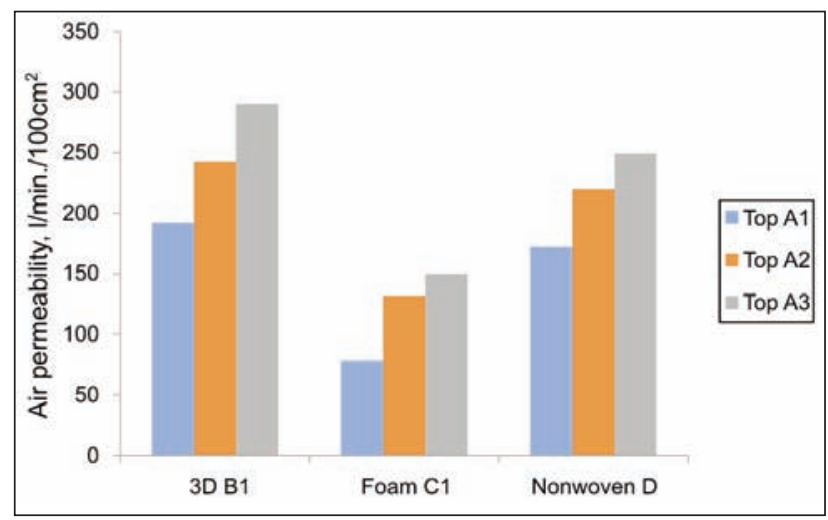

Fig. 6. Air permeability of the fabrics

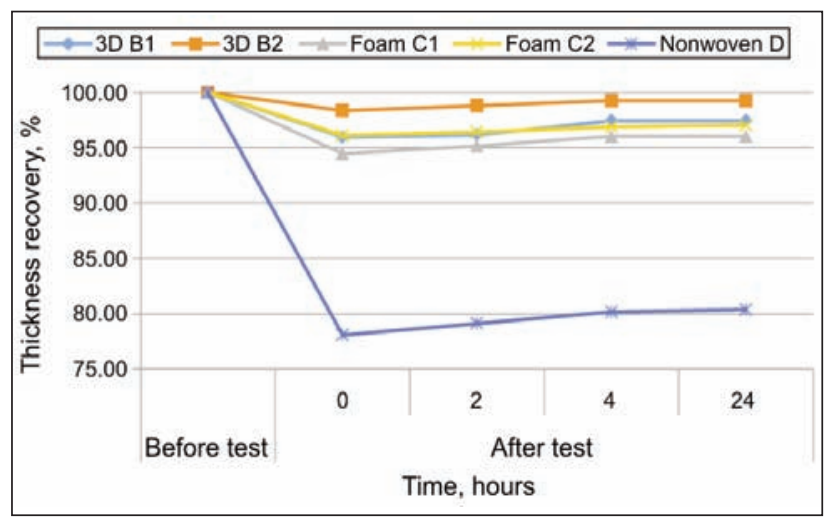

Fig. 7. Thickness recovery of tested samples within 24 hours after dynamic loading

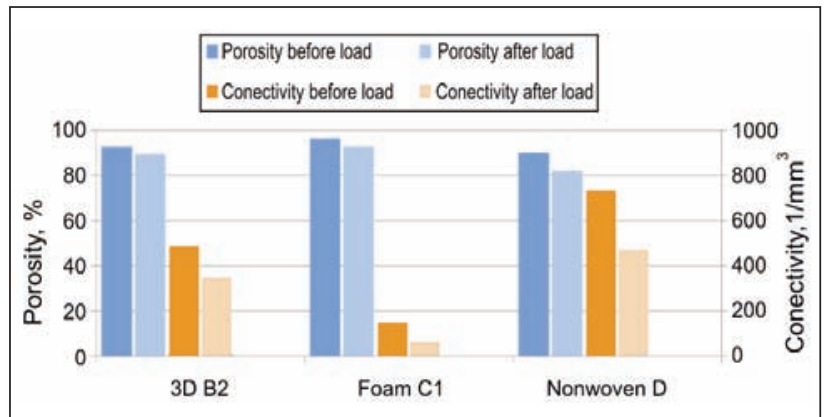

Fig. 8. Micro tomography analysis of tested car seat covers

of PU foam after loading is very similar to value before loading, but distribution of pores (frequency of individual classes of pore diameter) is changed. Part of small pores (diameter from 0 to $0.3015 \mathrm{~mm}$ ) disappeared because of pressure. Probably neighbouring cell walls of foam are joined together, effecting in decrease of connectivity. On the other hand, there are pores with increased size of cross section after loading. It can be caused by disruption of some cell walls in PU foam structure. The similar behaviour can be observed for nonwoven $D$. Increase of the middle and bigger pores is probably caused by dislocation of fibres in structure. Inner structure of 3D spacer B2 has been changed quite differently. There is increase of small pores (from 0 to 0.613 ) since big pores were "divided" by applied load, as shown in figure 9 . It is tion of tested samples has since supported the conclusions, as shown in figures 9-11. Total porosity

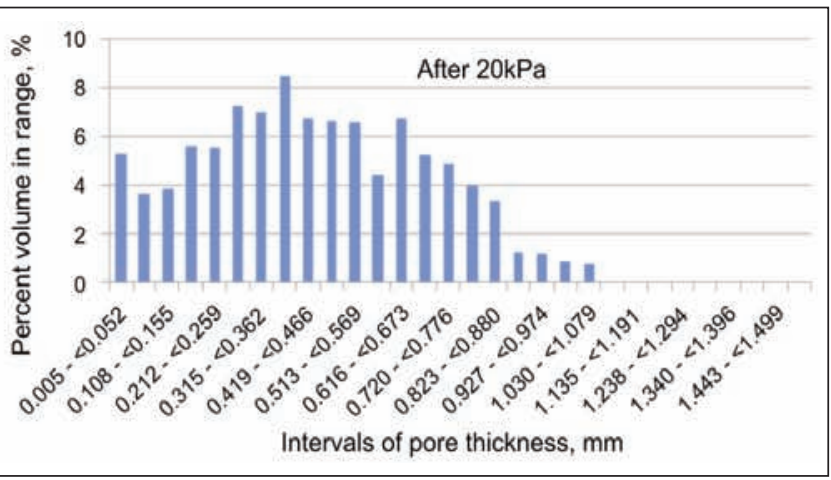

Intervals of pore thickness, $\mathrm{mm}$

Intervals of pore thickness, $\mathrm{mm}$

Fig. 9. Distribution of pores of 3D spacer B2 before and after dynamic load 


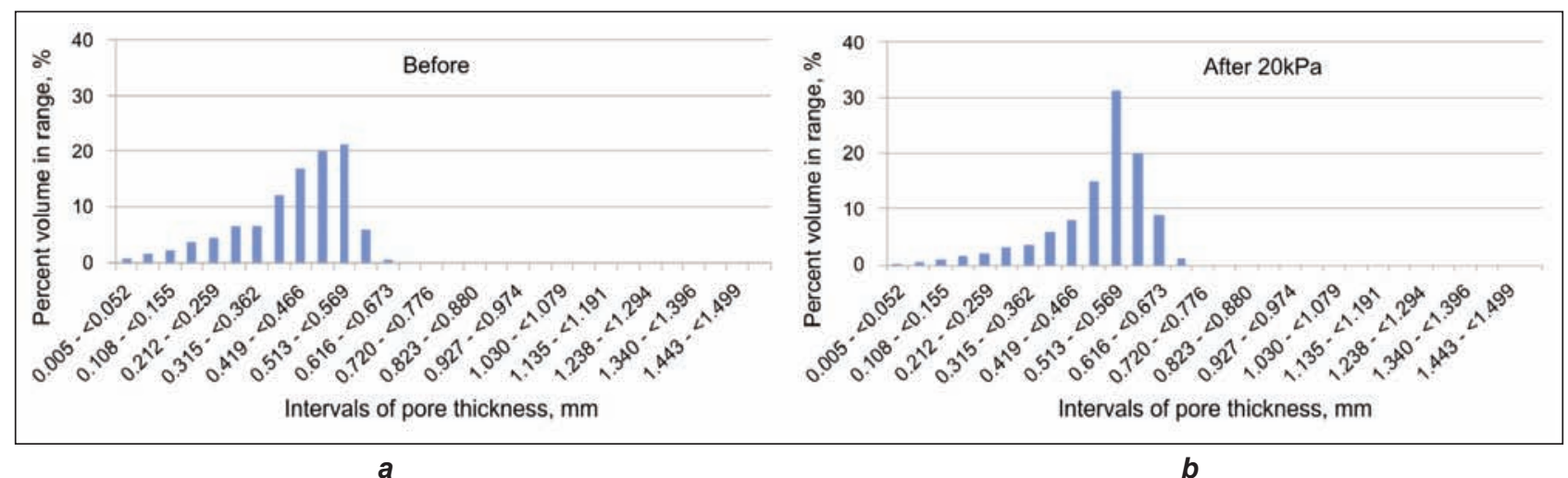

a

Fig. 10. Distribution of pores of PU foam C1: $a$ - before and $b$-dynamic load
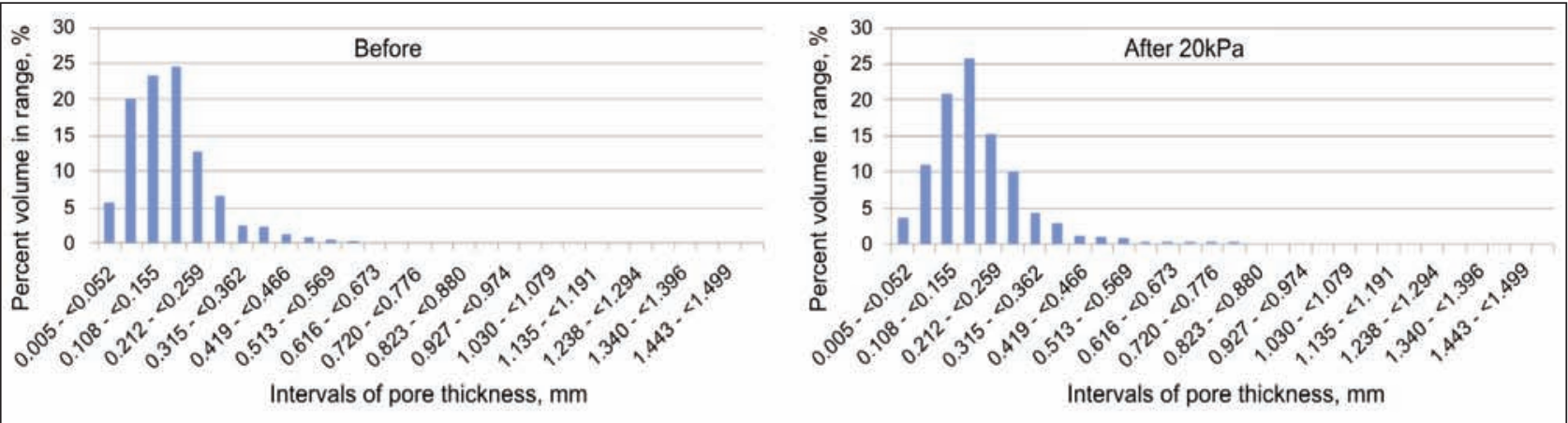

Fig. 11. Distribution of pores of nonwoven $D$ before and after dynamic load

conceivable that shape of big pore like "Q? "is is changed to pore with shape like "S" by compression. Notably it can be mainly caused by crossing of monofilaments in middle layer of 3D spacer.

\section{CONCLUSION}

This research extends the knowledge of car seat cover that considerably affects seating comfort. Tested group of car seat covers were investigated with respect to physiological properties and relaxation behaviour after dynamic compression loading. Results show both better mechanical durability and water vapour permeability of $3 D$ spacers than $P U$ foam or nonwoven padding. Further, influence of fibres cross section (of TOP layer of car seat cover) on degree of air permeability was confirmed. Analysis of pore size distribution in car seat structures by micro tomography system uncover following: pores size of 3D spacer are probably decreasing by crossing (of monofilaments in middle layer) after dynamic loading, on the contrary the pores size of PU foam are enlarged because of distortion of some partition of foam cells. Taken together, these results suggest that $3 \mathrm{D}$ spacer is the best for automotive. Nonwoven padding of car seat cover show low water vapour permeability and low durability given by reduction of their thickness after dynamic loading. PU foam is highly resistant to dynamic loading but its physiological properties are the worst. Further research will be focused on relation between long term stress on car seat covers and their moisture management properties.

\section{ACKNOWLEDGEMENTS}

This research work was supported by project OP VVV Hybrid Materials for Hierarchical Structures No. CZ.02.1. 01/0.0/0.0/16_019/0000843 and project No. LO1201 of the Ministry of Education, Youth and Sports in the framework of the targeted support of the "National Programme for Sustainability I".

\section{BIBLIOGRAPHY}

[1] Umbach, K.H. Physiological comfort of seats in cars, In: Kettenwirk-Praxis, 2000, vol. 24, issue 1, pp. 9-12.

[2] Scheffelmeier, M. and Classen, E. Measurement methods for investigation of thermos-physiological comfort in automotive seating, In: AACHEN Dresden International Conference, book of abstracts, 2014, p. 212.

[3] Fung, W. and Hardcastle, M., ed. Textiles in automotive engineering, In: Wood head Publishing limited Cambridge, England, UK, 2001. 
[4] Oi, H., Tabata, K., Naka, Y., Takeda, A. and Tochihara, Y. Effect of heated seats in vehicles on thermal comfort during the initila warm-up period, In: Applied Ergonomic, 2012, vol. 43, issue 2, pp. 360-367.

[5] Cengiz, T.G. and Babalik, F.C. An on the road experiment into the thermal comfort of car seats, In: Applied Ergonomics. 2007, vol. 38, issue 3, pp. 337-347.

[6] Rothe, D., Warp knitted spacer fabric - design and application fields, In: Knitting Technology. 2001, vol. 4, pp. 14-16.

[7] Bagherzadeh, R., Gorji, M., Latifi, M., Payvandy, P. and Kong, L.X., Evaluation of moisture management behaviour of high-wicking 3D warp knitted spacer fabric, In: Fibers and Polymers. 2012, vol. 13, issue 4, pp. 529-534.

[8] Yip, J. and Ng., S.P. Study of three-dimensional spacer fabrics: Physical and mechanical properties, In: Journal of materials processing technology, 2008, vol. 206, pp. 359-364.

[9] Havelka, A., Glombikova V. and Mazari, F.B. Monitoring thermophysiological comfort in the interlayer between driver and the carseat, In: Vlákna a textile. 2015, vol. 22, issue 3/4, pp. 40-45.

[10] Zhu, G., Kremenakova, D., Wang, Y., Militky, J. and Mishra, R., Study on the thermal property of highly porous novwoven fabrics, In: Industria Textila. 2015, vol. 66, issue 2, pp. 74-79.

[11] Koc, K. S., Mecit, D., Bozaci B., Ornek, M. and Hockenberger, A., Effect of filament cross section on the performance of automotive upholstery fabric, In: Journal of Industrial Textiles. 2015, DOI: 10.1177/ 1528083715598652 , pp. 1-15.

[12] Jerkovic, I., Pallares, J.M. and Capdevila, X. Study of the abrasion resistance in the upholstery of automobile seats, In: Autex Research Journal, 2010, vol. 10, issue 1, pp. 14-20.

[13] Ye, X., Fangueiro, R., Hu, H. and Araujo, M. Application of warp - knitted spacer fabrics in car seats, In: Journal of the Textile Institute, 2007, vol. 98, issue 4, pp. 337-343.

[14] Chen, S. and Long, H.R. Investigation on compression properties of polyurethane-based warp-knited spacer fabric composites for cushioning applications, Part II. Theoretical and experimental verification, In: Industria Textila, 2014, vol. 65, issue 6, pp. 340-344.

[15] Stämpfli, R. Brühwiler P.A., Rechsteiner, I., Meyer, V.R. and Rossi, R.M. Xray tomographic investigation of water distribution in textiles under compression - possibilities for data presentation, In: Measurement. 2013, vol. 46, issue 3, pp. 1212-1229

[16] Doczyova, K., Glombikova, V. and Komarkova, P. Application of microtomography in textile metrology, In: Tekstilec. 2014, vol. 57, issue 1, pp. 4-11.

[17] Stewart, R., O'Bannon, T., Müller, M. and Beeh, F. Creating the next generation ingress/egress robot, In: SAE Technical Paper 1999-01-0628, 1999, doi:10.4271/1999-01-0628.

[18] Hu, J., Li, Y., Wong, A. S. W. and Xu, W. Moisture management tester: A method to characterize fabric liquid moisture management, In: Textile Research Journal, 2005, vol. 75, issue 1, pp. 57-62.

[19] Havelka, A. and Kus, Z. Device for fatigue testing of textiles and multilayer textile composites, national utility model application: 2014, Application number: 2014-30445, Registration number: 28065 http://spisy.upv.cz/UtilityModels/ FullDocuments/FDUM0028/uv028065.pdf

[20] Odgaard, A. Three-dimensional methods for quantification of cancellous bone architecture, In: Bone, 1997, vol. 20, issue 4 , pp. $315-328$.

Authors:

\section{VIERA GLOMBIKOVA ${ }^{1}$ PETRA KOMARKOVA ${ }^{1}$ \\ ANTONIN HAVELKA ${ }^{1}$ \\ MARCELA KOLINOVA ${ }^{2}$}

${ }^{1}$ Technical University of Liberec, Faculty of Textile Engineering, Department of Clothing Technology, Studentska 1402/2, Liberec, Czech Republic, phone: +4204853543201, fax: +420485353204

${ }^{2}$ Technical University of Liberec, Institute for Nanomaterials, Advanced Technology and Innovation, Bendlova 1409/7,Liberec, Czech Republic, phone: +420 485353 865, fax: +420485353204

Corresponding author:

VIERA GLOMBIKOVA

viera.glombikova@tul.cz 